\title{
Analyzing Patent Information on Canning Technology for Food to Enhance Potential Industrial Development
}

\author{
Tommy Hendrix
}

Technology and Innovation Policy and Management, Indonesian Institute of

Sciences, Indonesia,Email:tomm001@lipi.go.id

\section{Article Info Abstract}

Keywords:

Analyzing; Canning Technology for

Foods; Enhance; Patent

Information; Potential Industrial

Development.

\section{How to cite:}

Tommy Hendrix, "Analyzing

Patent Information on Canning

Technology for Food to Enhance

Potential Industrial Development,"

Fiat Justisia: Jurnal Ilmu Hukum

14, 2 (2020): 141-158.

DOI:

10.25041/fiatjustisia.v14no2.1772
Modern movement has many impacts from $R \& D$ results, which becomes a general issue enabling technology enhancement to enter market requirement, primarily from portfolio through patent analysis. A patent is an intellectual property right granted under the law to protect an invention toward infringement. From patent information occurs product technology, especially connected to process that influences growth and restructuring of industrial leverage to enhance the economics of a community. Canning technology for foods as the entity of industrial process captures and introduces the chance of potential, innovative, and efficient strategies for global knowledge from appropriate technology and offers the possibilities for implementation based on reducing tools specification, timing process, and operational budgeting. The purpose of this paper is to know the competition among the same product through the utilization patent database registered on WIPO fields with patent analysis. The method in this research is patent analysis using Innography software from online WIPO database as potential leading patent-issuing authorities with 1747 patent document that is registered. This study intended as a reference and recommendation in the information for product canning technology for food benchmarking, which tailor to the capabilities and capacity $R$ \& $D$ results from differences in significance innovation development for commercial in market needs. 


\section{A. Introduction}

Development acceleration on appropriate technology nowadays becomes a significant issue in enhancing model technology that can be used by industry. The development of a product cannot be fulfilled in a short period, and it needs to see beneficiaries through analysis capability of a technology that differs from other products. The new dimension engages with hope of the settlement of new technology that appears as a solution for the users. Inline competition between industries through the technology development that turns any system of the world economy is experiencing a shift towards the formation of the global economic system. The development of current technology is not something new to increase national competitiveness. It is formed through a process of technology transfer dynamics, which is on-site technology so that it can assist users in applying the technology required. An optimal technological development can create outer product forms that are unstable and became a crack the entry of competitors in the form of a superior. The process of commercialization of product development is an alternative way of balancing the high demand market of similar products that have a high economic value. Development of economic value will bear into the industrialized system when new technology introduces in the market and have advantages on covered issue primarily. Successful commercialization of innovation requires that the know-how in question used in conjunction with other capabilities or assets. ${ }^{1}$

Derivative technology from R \& D results can be a solution in industrial acceleration through patent information. For example, the implementation of canning technology for foods, especially in the process of foods, needs protection to ensure the development authenticity in market orientation. The patent application was a part of the $\mathrm{R} \& \mathrm{D}$ result that is registered by the patentee for protection against infringement. This means an effort to understand in the role of intellectual property right (IPRs) tend as a "cost center" and not as "asset center". ${ }^{2}$ With the globalisation of markets and the increase in trade and investment flows across borders, impacted technology and technology-intensive products. ${ }^{3}$ This difference in national IPR standards has taken on additional significance. Firms have searched in foreign markets to sell their goods and to foreign destinations as platforms for production, making it easier for intellectual property to be accessed and copied in countries

\footnotetext{
${ }^{1}$ Tushman Michael L and Anderson Philip, Managing Strategic Innovation and Change, Collection of Readings (New York, Oxford: Oxford University Press, 1997).

${ }^{2}$ R. McDonald, "Contingent Capital with a Dual Price Trigger," Journal of Financial Stability 9, 2 (2013): 230-241. https://doi.org/10.2139/ssrn.1553430.

${ }^{3}$ C. C. A. Fink, Braga P, "How Stronger Protection of Intellectual Property Rights Affects International Trade Flows", (2005), in C. Fink and K. E. Maskus, Intellectual Property and Development: Lessons from Recent Economic Research (Washington, DC: The World Bank /Oxford University Press, 2005).
} 
that provide weak IPR protection. That is one of the primary reasonswhy firms investing heavily in $R \& D$ put pressure on national governments to strengthen the international IPR regime. ${ }^{4}$ The outcome was the Agreement on TradeRelated Aspects of Intellectual Property Rights (TRIPS), a product of the Uruguay Round (1986-94) of trade negotiations. TRIPS is the first comprehensive and global set of rules covering IPR protection. ${ }^{5}$

Through patent analyses, information databases and the utilization of patent is an attempt to emphasize competitiveness in order to open up market access to both national and international. The analogy to a patent application can infer that analyzing patents is most worthwhile to manage the complexities of searching and inter-relating patent information. ${ }^{6}$ A patent represents an invention in a particular field of technology, and also previous studies portray that a considerable part of the information presented in patents is relatively new ${ }^{7}$. In line with patent analysis, regarding canning technology for foods potential to be developed due to appropriate production process technology, the increase in market share, attractive packaging that favored consumers, and an affordable price.

Canning technology is one of the prospecting machinery to reduce the amount of heat used to preserve food in a quite long time. This technology proves in the food industry in line with the capability to enhance economic development.The purpose of this paper is to provide information related technologies that can be utilized by users as well as through the implementation of the technology transfer canning technology for foods based on patents that have registered. Patent analysis using Software Innography aims to know the orientation of the development of technology to market through licensing, patent portfolio, status, competition, innovation, and market monitoring derived from the database of patents. Moreover, it is useful for policymakers as recommendations for stakeholders in choosing alternative technologies that are appropriate market-oriented. A patent enables to understande the growing technology trend of the moment, knowing the player technology and even competitors who rule specific technologies, especially in the field of canning technology for foods. Understanding and analysis the the information in a patent analysis can capture opportunities or adopt the

\footnotetext{
${ }^{4}$ R. Falvey \& N Foster, 2006, The Role of Intellectual Property Rights in TechnologyTransfer and Economic Growth: Theory and Evidence. Accessed on http://www.researchgate.net/publication /22877802.

5 United Nations Conference on Trade and Development, The TRIPs Agreement and Developing Countries (Geneva: UNCTAD, 1996).

${ }^{6}$ Bonino D, Ciaramella A, Corno F, "Review of the State-of-The-Art in Patent Information and Future Evolutions in Intelligent Patent Informatics," World Pat Inf 32, 1 (2010): 30-8. https://doi.org/10.1016/j.wpi.2009.05.008.

${ }^{7}$ Hunt D, Nguyen L, Rodgers M, Patent Searching: Tools and Techniques (USA: John Wiley and Sons, 2007).
} 
technology gaps, as well as utilizing the technology. This can even develop into a better direction over the existing technology. Therfore, competitive activities to the potentially new invention in current technology development is large.

This research uses a qualitative research methodology approach, with literature study on patent information, analysis documents of the patent through data mining and information related to the topic of research by focusing on the search answers to research issues. As the systematic development of theory in social settings and it depends upon inductive approaches, which is appropriate for the study mainly aim at theory development. ${ }^{8}$ Qualitative research is used to explore the potential antecedents and factors about which little has known and explored. ${ }^{9}$ Data mining and information are conduct with two approaches, namely:

1. The study of literature seeks information related to the topics and issues from a variety of sources, such as books, journals, articles, or other writings of experts. Data mining is one of the methods or processes for extract the hidden patterns of specific data collections that emphasize the stages of data mining most essential to transforming data into information patent. ${ }^{10}$

2. Analysis of the database (benchmarking) from potential patent documents technology of canning food through Innography software whit sourced on the World Intellectual Property Organization (WIPO) database. In order to find some information related to research topics through the international patent classification (IPC) database that connected to research and development of civilization canning technology for food and to provide the latest research on a patent analysis in a unified form.

The purpose of this paper is to understand the information through international patent databases associated to the results of the research and development of canning technology for food. Whereas the object of this search and data analysis is to find result of research both applied and in progress so that it is aware of technology trends and current research in progress.

The analysis result of the patent can use both strategic management and applications, especially in the dissemination of appropriate technologies. ${ }^{11}$ This paper can be implementated or applied, where results are expected to be

\footnotetext{
${ }^{8}$ B. G.Glaser, \&A. Strauss, The Discovery Grounded Theory: Strategies for Qualitative Inquiry (Chicago: Aldin, 1967).

9 A. Strauss, \& J. Corbin, Basics of Qualitative Research: Techniques and Procedures for DevelopingGrounded Theory, $2^{\text {nd }}$ ed. (Thousand Oaks, London, New Delhi: Sage Publications, 1998).

${ }^{10}$ L.Yanhong, T. Runhua, Text Mining BasedPatent Analysis in Innovative Product Process (Boston: Springer Verlag, 2007). https://doi.org/10.1007/978-0-387-75456-7_9.

${ }^{11}$ T. Hendrix, "Implementation of Research and Development Based on Patent Natural Ingredient and Potential Utilization of Tradition Medicine," the Asian Journal of Technology Management 9, 1 (2016): 8-20.
} 
utilized by users. Specifically, this paper is a process of dissemination of patent and reverse engineering from a information sourced technology patent.

\section{B. Discussion}

Analyzing of patent portfolio result aims to find the measurable development of technology, especially canning product support for foods that users need that is based on patent searching where the market will introduce with a broad range of diversification models. The goals that appear from analyzing and discussion mainly derived from the assumption of how the prevention of patent litigation can pursue in the court of law. The system was generating and becomes example on first-to-file which is now universal and used in all countries, including the US. The system switched to first-to-file when the America Invents Act signed into law in 2013. That means that even if a person had already developed an idea unless they have already filed to begin the patenting process, the idea would still be up for ownership. ${ }^{12}$

The source of data analysis appears by using software development called Innography, due to the process held with entering the right keyword to determine the possibilities of a data requirement. Semantic-based text mining techniques rely on domain knowledge and create a relationship among domain-specific concepts. ${ }^{13}$ Urgency of a searching application, delivers many fields of information related to technology process that can be used from registration of an international patent. Methods used to produce specific products and test the effectiveness of a particular product.

The keyword "Canning Technology for Food" was found from a 1747 patent document that registered in the WIPO database. Description of years listed from 1992 until 2018 with the date of searching patent database on April 29,2019 . With in-depth analysis and visualized from many components that inline into software, selected maximal patent document such as searching top 20 on the title, using a type of table, pie chart, figure, heat, radar we found data result is mention below;

\section{Number Patent Filled Per Year on Canning Technology for Foods}

A patent is a document filled out legal rights for any invention, the proposal submitted and approved through the registration process. Data mining results on canning technology for foods shown various technology that been registered each year in the WIPO database numbered 1615 patents. It shows productivity that comes along with the requirement on market needs,

\footnotetext{
12 Patent Litigation. April 11, 2019. Accessed on https://www.morningtrans.com/what-ispatent-litigation.

${ }^{13}$ Bonino D, Ciaramella A, Corno F, Loc.Cit.
} 
as shown in table 1. When thepatent time limit expires, the production also comes to an end, and the patentee no longer holds the right to the discovery. Any discovery related to the product and process that is useful forindustrial application and is new can be patented. ${ }^{14}$ The patent filing procedures difference in application from one country to another and have many roles might apply regarding their needs for protection.

\section{Table 1. Top 5 Country Patent Filling Per Year for Canning Technology for Foods}

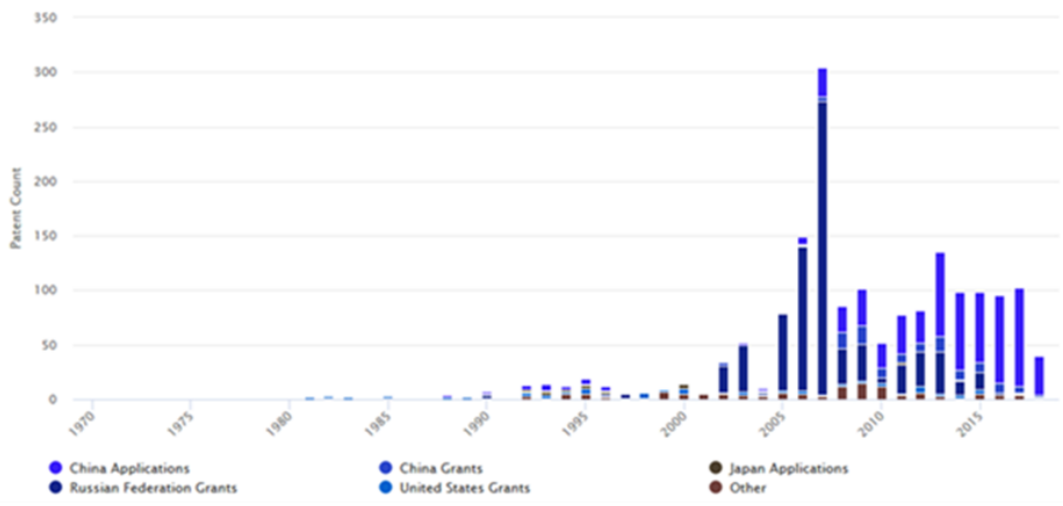

Notes: Patent Searching Filling Per-Year for Canning Technology for Foods Source: Innography Software, 2019

From description table 1, we see many total patents that have registered since 1992 until 2018 as in, China Application 605 patent, Russian Federation Grants 745, China Grants 116 patent, United States Grants 43 patent, Japan Application, and Other 121 patent. This patent filing information, based on the top 5 countries are recorded in the WIPO database with all description that refers to the term of requirement document. Grant means a patent already issue numbering from patent authority office and application mean patent still under process examination and filled.

\section{Inventor on Canning Technology for Foods}

Inventor is defined and identifies as the creator of an invention and also as an individual who makes original contribution to the invention and an intellectual contribution as defined by the claims of the patent application. Besides that, a person as inventor must generate the idea, materially contributes to the development of the invention, provides solutions to

\footnotetext{
14 V. Kumar, "Patent Filing and Drafting Procedure in India for a New Pharmaceutical Product," Innoriginal International Journal of Sciences 5, 4 (2018): 13-16.
} 
problems, and implements the innovation of inventor as described place of work so can determine the connection with inventors. A patent is the legal right of an inventor to exclude others from making or using aparticular invention. This right is sometimes termed an "intellectual propertyright" and viewed as an incentive for innovation. ${ }^{15}$

Figure 3. Top 20 Inventors on Canning Technology for Foods in \% Patents

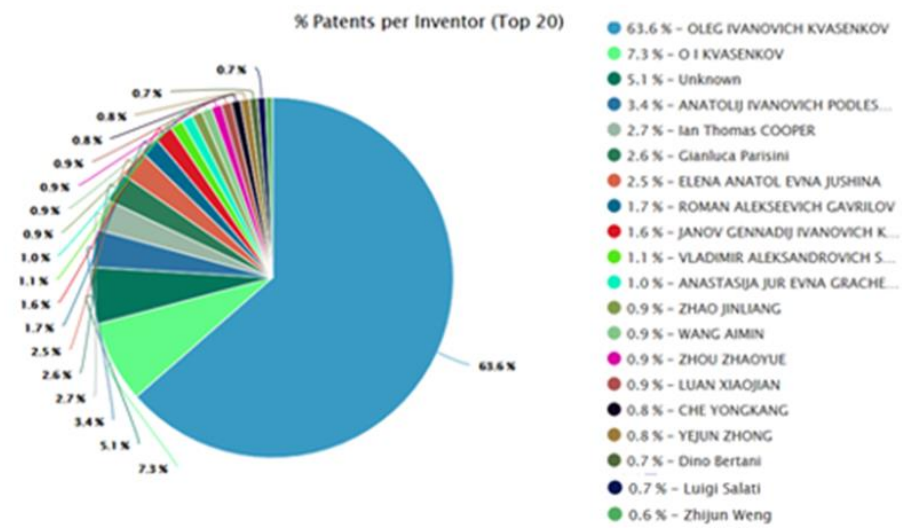

Notes: Patent Searching Top 20 Inventors on Canning Technology for Foods in \% Patents

Source: Innography Software, 2019

From figure 3, we can describe inventors in the top 5 patent holders that produce patent technology in canning for foods. They aconsist of Oleg Ivanovich Kvasenkov with 698 patents; Unknown Inventors from difference inventors produced 50 patents; Anatolij Ivanovich Podlesnyj has produced 33 patents; Ian Thomas Cooper has produced 27 patents; Gianluca Parisini has produced 26 patents.

\section{Location Inventors on Canning Technology for Foods}

Location inventor is a place that inventors registered their patent document in a country authority that in charge of filling patent registration in different countries for their own management patent office. In figure 4, the overview location that patent has already registered with the results of 1747 Patents from the top 20 Countries of 31 Total. The "networks" matter for technological innovation nowadays supports the data's precision. In fact, it is widely recognized that both the creation and the diffusion of new ideas are

\footnotetext{
${ }^{15}$ H. B. Hall, Patents and Patent Policy, (UK: Oxford Review of Economic Policy, 2007).
} 
processes that imply the integration and recombination of existing knowledge coming from differentsources, locations, and organizational positions. ${ }^{16}$

\section{Figure 4. Patents per Inventor Location on Canning Technology for Foods}

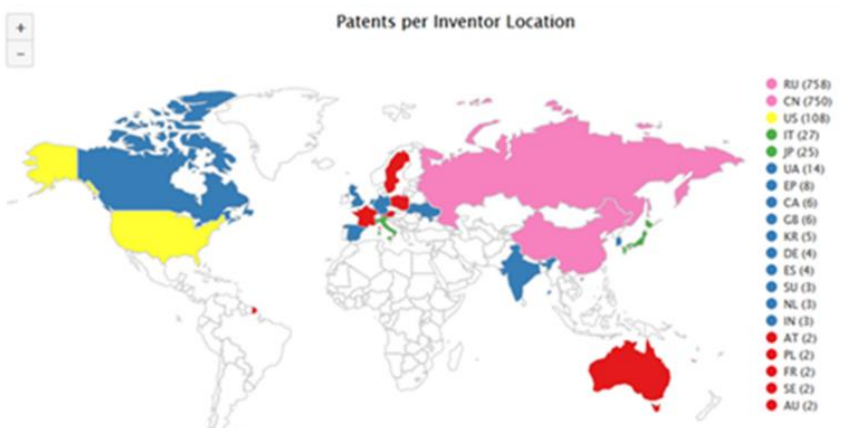

Notes: Patent Searching per Inventor Location on Canning Technology for Foods Source: Innography Software, 2019

Data shows the spreading of location where patent has been registered from many country, such as Romania Patent Office (Marcaria) with 758 patents, China National Intellectual Property Administration (CNIPA) 750 patent, United States Patent and Trademark Office (USPTO) 108 patent, Italian Patent and Trademark Office (UIBM) 27 patents, Japan Patent Office (JPO) 25 patents, Ukrainian Intellectual Property Institute (UKRPATENT) 14 patents, European Patent Office (EPO) 8 patents, Canadian Intellectual Property Office (CIPO) 6 patents, Intellectual Property Office (IPO) United Kingdom 6 patents, Korean Intellectual Property Office (KIPO) 5 patents, German Patent and Trademark Office (DPMA) 4 patents, Spanish Patent and Trademark Office (OEPM) 4 patents, Eurasian Patent Organization (EAPO) Soviet Union 3 patents, Netherland Patent Office (NPO) 3 patents, Intellectual Property India (IPINDIA) 3 patents, Austrian Patent Office (APO) 2 patents, Patent Office of the Republic Poland (PPO) 2 patents, National Institute of Industrial Property (INPI) France 2 patents, The Swedish Patent and Registration Office - Intellectual property (PRV) 2 patents, Intellectual Property (IP) Australia 2 patents.

\section{The Organization on Canning Technology for Foods}

\footnotetext{
${ }^{16}$ S. Breschi, F.Lissoni, Knowledge Networks from Patent Data: Methodological Issues and Research Targets. Handbook of Quantitative Science and Technology Research: The Use of Publication and Patent Statistics in Studies of S\&T Systems, (2005), 613-643. https://doi.org/10.1007/1-4020-2755-9_29.
} 
The organization is the same association with Patent Assignee means a person who holds and has a valid assignment in writing, the whole interest of a patent, or any whole part of such overall interest, including ownership rights of the intellectual property. It means exclusive right to make, use, and vend the patented improvement during the term for which the patent granted. Figure 5 shows the organization that owns cooperation in patent application with an inventor. The countries owning patents with more forward citations have a robust technological impact in comparison to a backward citation that depicts countries with mature technologies. If further indicates the R \& D ability of assignee ${ }^{17}$.

\section{Figure 5. Organization (Bubble Style) on Canning Technology for Food}

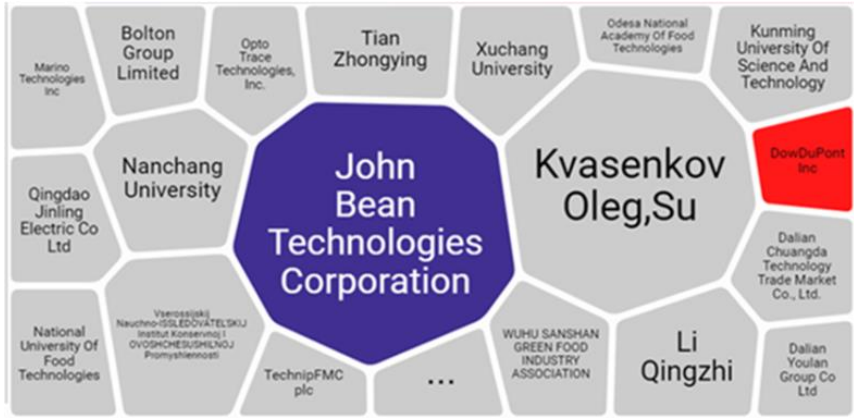

Notes: Patent Searching Organization on Canning Technology for Food Source: Innography Software, 2019

Patent terminology is used in industries as a proven technology this is very useful in order to see competitions in market orientation. For example, the needs of technology will bring the efficiency of economic development indirectly through product diversification, especially in canning technology for food sectors. From figure 3 with 882 Patents, Top 20 Organizations of 510 total, can be described as a technology push to industries process on 5 top patents assignee such as John Bean Technologies Corporation, an American food processing machinery and airport equipment company. JBT Corporation was incorporated in 2008 when FMC Technologies divested its non-energy businesses. ${ }^{18}$ It has claimed 29 patents and a total revenue of $\$ 1.635 .100 .000$. Oleg Ivanovich Kvasenkov has 24 patents, Li Qingzhi with has 9 patents, Tian Zhaoying with also 9 patents. DowDuPont is an American company formed

\footnotetext{
${ }^{17}$ D. Mehrotra, S. Sabitha, R. Nagpal, N. Mattas, "Landscape Analysis of Patent Dataset," Journal of Intellectual Property Right 21 (2016): 211 - 225.

18 Wikipedia. (2019). JBT Corporation. Retrieved from, April 11, 2019. Accessed on https://en.wikipedia.org/wiki/JBT_Corporation.
} 
after the merger of Dow Chemical and DuPont on August 31, 2017. It is the world's largest chemical company in terms of sales with five patents and total revenue of $\$ 85.977 .000 .{ }^{19}$ From the description above, only two company have established revenue from the organization who implement cooperation between assignment a patent to a company. Moreover, the rest was doing their commitment regarding cooperation in technology transfers into a company.

\section{Patent Litigation on Canning Technology for Foods}

Another party will not use the act of law by the inventor (patent owner) in order to guarantee the patent. This patent litigation is the legal process that unfolds when someone who owns the patent for a particular invention enforces their right by using another for manufacturing or selling the invention without permission..$^{20}$ Transformation can be see-through Bubble Market and Patent Litigation in figure 6.A. the patent scope can manifestly be designed to discourageentry. Broad and short patents can be designed to discourage imitation, but licensing and threat of litigation can also potentially serve as entry deterrence. ${ }^{21}$ This indicates that the value of a patent strongly depends both ex-ante, when a designer of the patent claims and ex-post in the competency of the innovator's legal department or the legal advisers. ${ }^{22}$ In a non-cooperative game approach, the litigation process is an opportunity to engage in strategic behavior when the validity of the patent will be challenged in court. ${ }^{23}$

\section{Figure 6. Patent Litigation on Canning Technology for Foods}

\footnotetext{
19 Wikipedia, DowDuPont Inc. Retrieved from, April 11, 2019. Accessed on https://en.wikipedia.org/wiki/DowDuPont.

20 Patent Litigation, April 11, 2019. Accessed on https://www.morningtrans.com/what-ispatent-litigation.

${ }^{21}$ N. Gallini, "Patent Policy and Costly Imitation," Rand Journal of Economics 23, 1 (1992): 52-63.

${ }^{22}$ H. L. Speight, "Unless One is Willing to Sue on it, a Patent is Virtually Useless, just a Fancy Piece of Paper with a Gold Seal thatLooks Good on the Wall," The National Law Journal 22, (1998).

${ }^{23}$ M. J. Meurer, “The Settlement of Patent Litigation," RAND Journal of Economics,Spring 20, 1 (1989): 77-91.
} 


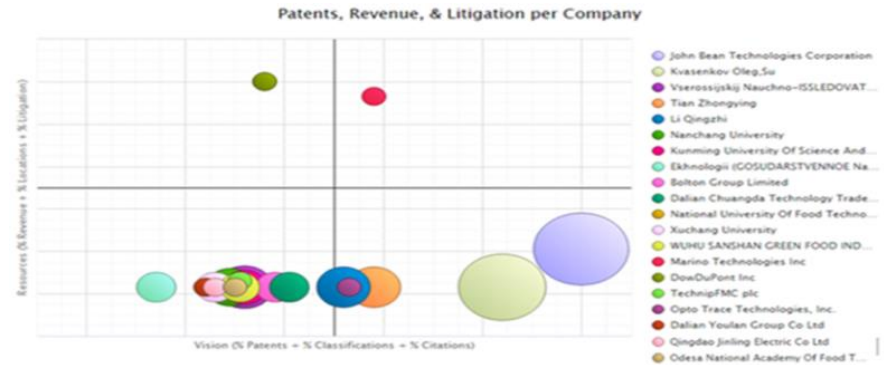

Notes: Patent Searching Litigation on Canning Technology for Foods Source: Innography Software, 2019

From patent litigation on canning technology for foods, there are three companies with lawsuits. These are because both parties are trying to claim ownership of the same idea or invention. Recording to figure 4 can see that John Bean Technologies Corporation has four processes of patent litigation, DowDuPont Inc. has 370 processes of patent litigation, and Marino Technologies Inc. have process one patent litigation.

\section{International Patent Classification (IP Class) on Canning Technology for Foods}

Competitiveness is a typical characteristic of industrial technology ${ }^{24}$. Practically, for almost every emerging industry, some kinds of technology will become leading and predominant after developing over a while. ${ }^{25}$ According to Porter's theory of competitive advantage, the real competitors inside the industry are companies similar to a company. ${ }^{26}$

Due to the different areas of technology, the derivative search of International Patent Classification on canning technology for foods can be defined to provide the clustering system of independent symbols for the classification of patents and utility models. These IP Class established by the Strasbourg Agreement 1971, provides for a hierarchical system of language independent symbols for the classification of patents and utility models based on the different areas of technology to which they pertain that source from World Intellectual Property Organization (WIPO). Figure 7 shows the leveling IP Class that represents classified patents at class, subclass, leading

24 B. Yoon, S.Lee, "Patent Analysis For TechnologyForecasting: Sector-Specific Applications," C. IEEE International Engineering Management Conference (2008). https://doi.org/10.1109/iemce.2008.4617997.

${ }^{25}$ Y. Fu, H. Han, L. Zhu, "Patent Technology Competitor Group Analysis Method Based on IPC. Proceedings of the Second International Workshop on Patent Mining and its Applications (IPAMIN)," May 27-28, Beijing, China (2015).

${ }^{26}$ C. K. Lee, R. Ong, "An Analysis of The LiquidCrystal Cell Patents of LG and Samsung Filed at the USPTO," $C$. IEEE International Conference on Management of Innovation and Technology, (2006). https://doi.org/10.1109/icmit.2006.262181. 
group, or subgroup level with result 1747 Patents, Top 20 IPC Groups of 168 Total.

\section{Figure 7. IP Class on Canning Technology for Foods}

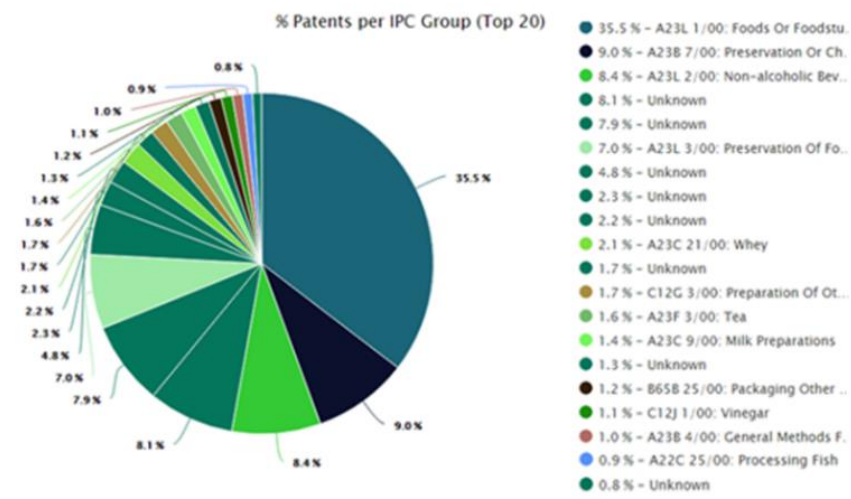

Notes: Patent Searching IP Class on Canning Technology for Foods Source: Innography Software, 2019

The figure above shows that top 3 IP class on canning technology for foods consist of A23L 1/00 have 505 patents (35,5\%) with description A (Section A Human Necessities); A23 (Foods or Foodstuffs; Their Treatment, Not Covered by Other Classes); A23L 1/00 (Their Preparation or Treatment, Modification of Nutritive Qualities, Physical Treatment, Preservation of Foods or Foodstuffs, In General), A23B 7/00 have 128 patents (9\%) with description A (Section A Human Necessities); A23 (Foods or Foodstuffs; Their Treatment, Not Covered by Other Classes); A23B 7/00 (Preservation or chemical ripening of fruit or vegetables), A23L 2/00 have 119 patents $(8,4 \%)$ with description A (Section A Human Necessities); A23 (Foods or Foodstuffs; Their Treatment, Not Covered by Other Classes); A23L 2/00 (Non-alcoholic beverages; Dry compositions or concentrates therefor; Their preparation).

From listing 3 IP Class can be analyzed that sectors of IP Class all in A Human Necessities with total dominant around 917 patents, it means the probability of canning technology, especially in the foods sector dominant in using for a daily personal requirement.

\section{Patent Strength (Bar) and Factor (Radar) on Canning Technology for Food}

The qualitative method uses the Innography tool for measuring strength and factor of patent portfolios by applying this method to these areas. Their qualitative values have been obtained, where in the strength of these patent portfolios can show on the analysis below. A framework for the evaluation and strategic management of patent portfolios and development projects can 
be obtained to integrate the intellectual property into a social management strategy. ${ }^{27}$

Patent strength was product average of quality and activity, especially for a company interested in representing competitive technologies positions off all competitor fields. The strategy of a company was a part of the business by evaluating the activity that measures the successful technology innovation reflecting technology leaders in the market. Figure 8. Shows results from 1747 Patents, Top 10 Patent Strength Deciles.

\section{Figure 8. Patent Strength Deciles on Canning Technology for Foods}

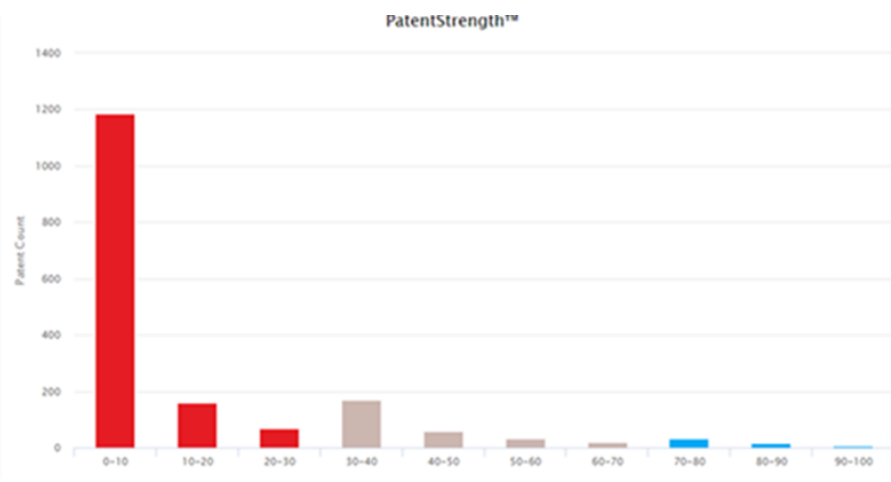

Notes: Patent Searching Strength Deciles on Canning Technology for Foods Source: Innography Software, 2019

From the deciles on patent strength it seems many patents still in lower point, especially for industries application with calculation 10 deciles level 0 -10 have 1184 patents, $10-20$ have 161 patents, $20-30$ have 67 patents, 30 - 40 have 168 patents, 40 - 50 have 60 patents, $50-60$ have 32 patents, 60 70 have 21 patents, $70-80$ have 31 patents, $80-90$ have 17 patents and $90-$ 100 have 6 patents. Definition from patent strength according to data in figure 8 , decile means patents number can incorporate different factors, both positive and negative, including the grant status, citation frequency, age, breadth, and examiner comments or office actions. An analysis gives a much clearer picture of the relative quality of the patent art for each business unit. Once the scores are assigned, they should be dissected to determine their meaning. Is the outside interest something that can leverage.

Strength factors (Radar) indicates the movement of patents, that is influenced by an average of the patent claim (indisputably the most important part of a patent specification and defines the boundary of the patent by the

${ }^{27}$ S. Nemet, M. Baric, F. Bencic, D. Kukolj, "Comparative Technology Assessment using Patent Evaluation. Conference Paper: Zooming Innovation in Consumer Electronics," Int. Conference ZINC, At Novi Sad (2018). https://doi.org/10.1109/zinc.2018.8448935. 
invention and therefore what is sought to be protected), especially for canning technology for foods in figure 9 .

\section{Figure 9. Strength Factors (Radar) on Canning Technology for Foods}

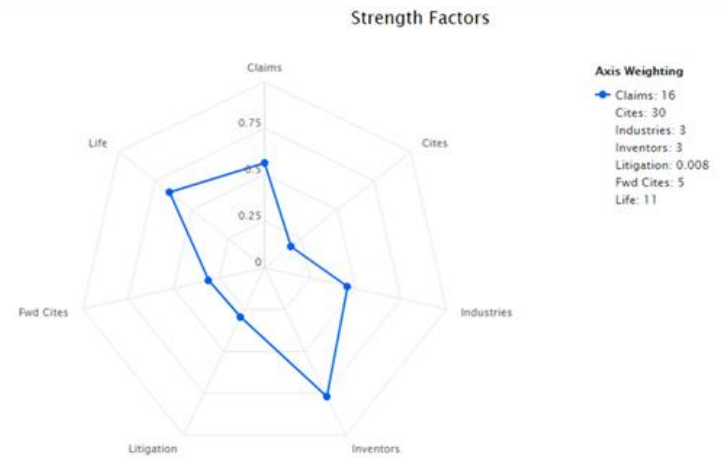

Notes: Patent Searching Strength Factors (Radar) on Canning Technology for Foods Source: Innography Software, 2019

Strength factors were encouraging users to find related information with dimensions of interaction regarding survivability intelligence when meeting court challenges such as litigation, industries, claim, live, inventor, cites, fwd cites. The average number shows all dimension;

a. Patent litigation is the act of law when someone who owns the patent for a particular invention enforces their right by using another for manufacturing or selling the invention without permission. Data interaction with average number 0.294758 from axis weighting 0.008 means patent litigation has a high impact on protecting patents from infringement or violation of the law.

b. Patent Industries mean the implementation of countries' patent rights fall under civil law, and the patent holder needs to sue someone infringing the patent in order to enforce his or her rights with average number 0.456091 . Data interaction with average number 0.456091 from axis weighting 3 means patent industries have a low impact from industry application.

c. Patent Claim means to define the scope of what claimed as the invention that limits coverage of patent protection with an average number of 0.563665 . Data interaction with average number 0.563665 from axis weighting 16 mean patent claims have low limits of precisely what the patent does, and does not, cover.

d. Patent Life is the maximum period during it maintains in force from the filing date of the patent application or the date of grant of the patent with average number 0.651534. Data interaction with average number 
0.651534 from axis weighting 11 mean patent lives have a low impact from period protecting on filling until granted.

e. Patent Inventor is an inventor is a person or persons in patent law who contribute to the claims of a patentable invention with an average number of 0.769498 . Data interaction with average number 0.769498 from axis weighting three mean patent inventors has a low position on productive producing patents each year.

f. Cites A patent citation is a document cited by an applicant, third party, or a patent office examiner because its content relates to a patent application with an average number of 0.181837 . Data interaction with average number 0.181837 from axis weighting 30 mean patent cites have very low on citation each year and possible to target the acquisition of active patents, which results in the enhancement of $\mathrm{R} \& \mathrm{D}$ output and, consequently, much improved or new products.

g. Fwd Cites means the applicant and the patent examiner must find and cite documents that may anticipate the claimed invention or might be similar to the claimed invention and limit the scope of the patent protection, or which generally reveal the state of the art of the technology with average number 0.306609 . Data interaction with average number 0.306609 from axis weighting 5 mean FWD cites have a low impact on anticipating claim invention or similar invention from revealing state of the art.

\section{Conclusion}

Patent applications are an essential tool for promoting innovation and technology. The patent system creates a framework that supports an incentive for the R \& D result, which fosters innovation, technology transfer, and economic growth. When developing a new product, related technological information may determine the success or failure of the product and, in turn, the success or failure of the company itself. Patent documents represent a rich source of technical, legal, and business information presented in a generally standardized format and often not reproduced anywhere else.

The industrial development that links to technology nowadays is significant if we see from consumer goods. However, this enhancement gives more opportunity in industry development; mainly, metal packaging follows the trends of the global packaging market. Estimated at USD 102.9 billion in 2015, the global market is forecast to reach USD 106.1 billion in $2016(+3.1 \%)$ and USD 132.1 billion in 2021 ( $+4.5 \%$ per year). Demand comes from Asia, driven by China, and mainly focuses on aerosols for personal hygiene products, cosmetics, and cleaning products. On Western European and North American markets, canned foods are being impacted by competition from flexible packaging and by consumer's demand for fresh fruit and vegetables. However, cans for beverages, which represent $65 \%$ of the metal packaging market, continue to progress, driven by breweries and micro-breweries which 
compete with each other on design and individual formats. ${ }^{11}$ These data justified canning in the market has a significant impact on stakeholder needs regarding all functions of use.

From the total number of 1.747 documents patents, not all can track the patent database, because they are majorly unused. The discoveries are canning technology for foods drawn ineffective implementation with significant impact, especially industries assignee. From description IP Class still on A. Human Necessities, C. Chemistry, and B. Performing Operation, it means most of the derivative product has implemented to human consumption.

Data analysis has shown the use of patent information is rarely uses; this means utilization is based on personal interest or becomes information for market review. Industries often use secondary data for research and development in forecasting new variation of product to fulfill demand market competitiveness. Particularly in Indonesia, it cannot show because it still applies in a residential area, and application in an industry zero also cannot be displayed as a result of investigation data. On the other side, the policy recommendation from this paper requires the user to receive patent information technology database as a starting point to see more availability of technology to enter market orientation. This should be initiaited by government policy through awareness dissemination program with enhancement regulation scheme.

\section{References}

A. J. Scott, M. Storper. "Regions, Globalizations, Development." Regional Studies 37, (2003).

A. Strauss, J. Corbin. Basics of Qualitative Research: Techniques and Procedures for Developing Grounded Theory $\left(2^{\text {nd }} \mathrm{ed}\right.$.) Thousand Oaks, London. New Delhi: Sage Publications, 1998.

B. G., Strauss, A. The Discovery Grounded Theory: Strategies for Qualitative Inquiry.Chicago: Aldin, 1967.

B. Yoon, S. Lee. "Patent Analysis for Technology Forecasting: SectorSpecific Applications." C. IEEE International Engineering Management Conference,

(2008). https://doi.org/10.1109/iemce.2008.4617997.

B. P. Abraham, S.D.Moitra. "Innovation Assessment Through Patent Analysis." Technovation 21, 4 (2001). https://doi.org/10.1016/s01664972(00)00040-7.

Bender, A.E. Chapter 5 in Food Processing and Nutrition.USA: Academic Press, 1978.

Breschi, S., Lissoni, F. Knowledge Networks from Patent Data: Methodological Issues and Research Targets. Handbook of Quantitative Science and Technology Research: The Use of Publication 
and Patent Statistics in Studies of S\&T Systems, 2005. https://doi.org/10.1007/1-4020-2755-9_29.

C. Fink and K. E. Maskus. Intellectual Property and Development: Lessons from Recent Economic Research.Washington. DC: The World Bank / Oxford University Press, 2005.

C. K. Lee, R. Ong. "An Analysis of the Liquid Crystal Cell Patents of LG and Samsung Filed at the USPTO." C. IEEE International Conference on Management of Innovation and Technology (2006). https://doi.org/10.1109/icmit.2006.262181.

D. Bonino, A. Ciaramella, F.Corno. "Review of the State-of-The-Art in Patent Information and Future Evolutions in Intelligent Patent Informatics." World Pat Inf 32, 1 (2010). https://doi.org/10.1016/j.wpi.2009.05.008.

D. Mehrotra, S.Sabitha, R.Nagpal, N. Mattas. "Landscape Analysis of Patent Dataset." Journal of Intellectual Property Right 21 (2016).

G. M. Coelho, D. M. S.Coelho. "Metodologias e ExperiênciasNacionais e Internacionais." Nota Técnica 14, Instituto Nacional de Tecnologia, Janeiro, (2016).

H. L. Speight. "Unless One is Willing to Sue on it, a Patent is Virtually Useless, Just a Fancy Piece of Paper With a Gold Seal that Looks Good on the Wall." The National Law Journal 22 (1998).

Hall, H. B. Patents and Patent Policy. UK: Oxford Review of Economic Policy, 2007.

Hunt D, Nguyen L, Rodgers M. Patent Searching: Tools and Techniques. USA: John Wiley and Sons, 2007.

M.J.Meurer. "The Settlement of Patent Litigation." RAND Journal of Economics, Spring 20, 1 (1989).

Mankiw, N.G., Taylor, M.P. Economics, South African Edition.1st Edition.Hamshire. UK: Cengage Learning, 2014.

N. Gallini. "Patent Policy and Costly Imitation," Rand Journal of Economics 23, 1 (1992). https://doi.org/10.2307/2555432.

P. Sharma, and R. C.Tripathi. "Patent Database: A Methodology of Information Retrieval from PDF." International Journal of Database Management Systems $5, \quad 5 \quad$ (2013). https://doi.org/10.5121/ijdms.2013.5502.

R. McDonald. "Contingent Capital with a Dual Price Trigger." Journal of Financial Stability 9, 2 (2013). https://doi.org/10.2139/ssrn.1553430.

S. Altuntas, T. Dereli, A. Kusiak. "Forecasting Technology Success Based on Patent Data." Journal Elsevier Technological Forecasting \& Social Change 96 (2015). https://doi.org/10.1016/j.techfore.2015.03.011.

S. Nemet, M. Baric, F. Bencic, D. Kukolj. "Comparative Technology Assessment using Patent Evaluation." Conference Paper: Zooming Innovation in Consumer Electronics Int. Conference ZINC (2018). https://doi.org/10.1109/zinc.2018.8448935. 
T. Hendrix. "Implementation of Research and Development Based on Patent Natural Ingredient and Potential Utilization of Tradition Medicine." the Asian Journal of Technology Management 9, 1 (2016).

Tushman, M. L., Philip, A. Managing Strategic Innovation and Change, Collection of Readings. New York, Oxford: Oxford University Press, 1997.

United Nations Conference on Trade and Development. The TRIPs Agreement, and Developing Countries. Geneva: UNCTAD, (1996).

V. Kumar. "Patent Filing and Drafting Procedure in India for A New Pharmaceutical Product." Innoriginal International Journal of Sciences 5, 4 (2018).

Winarno. Commercial Sterilization of Product Food. Jakarta: Gramedia Pustaka Utama, 1994.

Y. Fu, H. Han, L.Zhu. "Patent Technology Competitor Group Analysis Method Based on IPC." Proceedings of the Second International Workshop on Patent Mining and its Applications (IPAMIN), May 2728, Beijing, China (2015).

Yanhong, L., T. Runhua. Text Mining Based Patent Analysis in Innovative Product Process. Boston: Springer Verlag, 2007. https://doi.org/10.1007/978-0-387-75456-7_9.

All4pack. (2015). Estimation Data Emerging Market Packaging 2015 and 2020. Accessed on https://www.all4pack.com/Archives/Packagingmarket-challenges-2016.

Patent Litigation. (2018). April 11, 2019. Accessed on https://www.morningtrans.com/what-is-patent-litigation.

R. Foster N, "The Role of Intellectual Property Rights in Technology Transfer and Economic Growth: Theory and Evidence". April 11, 2019. April 11, 2019. Accessed on http://www.researchgate.net/publication 122877802 .

Wikipedia. (2019). Accessed on DowDuPont Inc. Retrieved from https://en.wikipedia.org/wiki/DowDuPont.

Wikipedia. (2019). April 11, 2019. Accessed on JBT Corporation.Retrieved from https://en.wikipedia.org/wiki/JBT_Corporation. 